\title{
GEOSTATISTICAL AND GEOPHYSICAL MODELLING OF THE OITTI DNAPL SPILL SITE, SOUTHERN FINLAND
}

\author{
Laine, Eevaliisa and Peltoniemi, Markku \\ Helsinki University of Technology, Laboratory of Engineering Geology and Geophysics \\ P.O.Box 6200, FIN-02015 HUT, Finland
}

\section{Introduction}

In the 1950's and 1960's about 10,000 litres of dry cleaning solvent was disposed of in a well or in pits (s1) near the town center at Oitti, southern Finland (Fig. 1). The groundwater was found contaminated in 1992 when a regional groundwater quality survey was done in the region. The old waste disposal dump (s2) (Fig. 1) forms an additional risk [1]. According to the inhabitants in Oitti, about $900000 \mathrm{~kg}$ waste material from the cleaning establishment was deposited to this dump. There is also a possibility that the polluted groundwater reaches the Päijänne tunnel situating in the bedrock and passing the Oitti village (Fig. 1). This tunnel conveys water from Lake Päijänne in inner Finland to the Helsinki water-deficit area.

The solvent consists mainly of trichloroethylene and tetrachloroethylene which are dense nonaqueous phase liquids (DNAPLs). These heavy solvents are partly dissolved to the groundwater and partly migrating to impermeable boundaries such as clay layers and the surface of the crystalline bedrock. Consequently, the main objective was the characterization of the clay layers and the bedrock topography using the geophysical profiling.

\section{DNAPL migration}

The Salpausselkä moraines were deposited in Baltic Ice Lake about 11,250-9,900 years ago during the latest ice age (Fig. 1). At Oitti, Salpausselkä moraines form two small parallel ridges in which cross-bedded sands and gravels coarsen upwards. According to the drilling logs [1], the soils around Oitti are very heterogenous. At a depth of 10 to 20 metres there is a clay layer that probably controls the migration of the heavy solvent. This clay layer has been detected by using the ground penetrating radar [3]. According to the results measured over the moraine, no impulses have penetrated the conductive clay layer. It appeared that this layer is discontinuous, and, probably, not capable to prevent the DNAPL migration downwards. Thus, the main controlling factor for the solvent migration is, after the dissolution into the groundwater, the bedrock topography.

The bedrock topography has been formed by the action of ice, fracturing and erosion. The data for the bedrock topography (Fig. 2b) was collected along the seismic profiles done during 

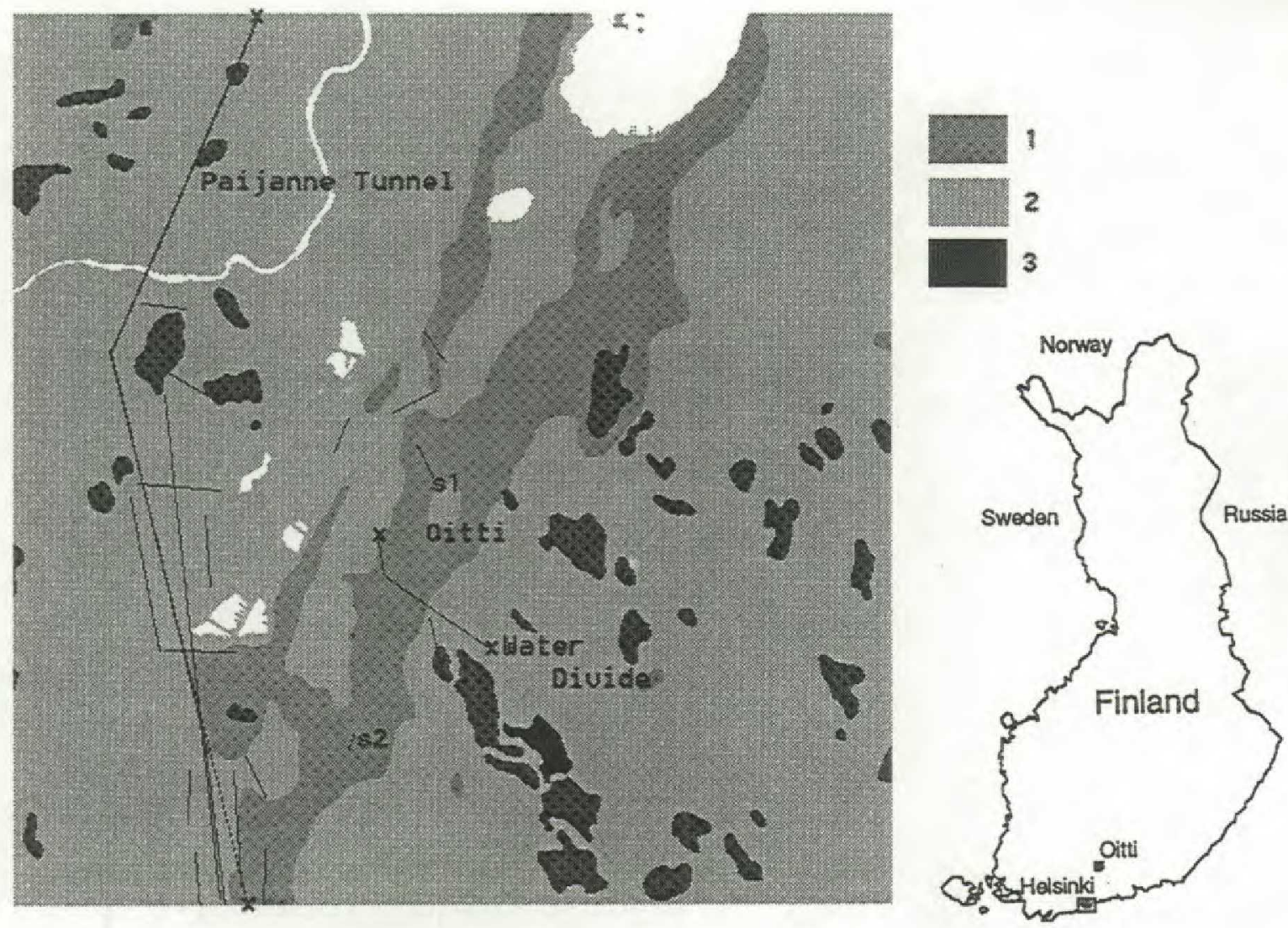

$\vdash 1 \mathrm{~km}-1$

Figure 1. The map of the surficial deposits of the Oitti area [2]. 1 - glacial moraine; 2 - other quaternary deposits; 3 - outcrops; $s 1$ - the spill site in Oitti; s2 - waste disposal dump. The black lines mark the refraction seismic profiles.

the planning phase of the Päjianne tunnel [4] and during the investigations of the the Oitti spill site [1]. Based on the variogram study, there are two main directions of continuity for the bedrock topography. The first one is directed along the Salpausselkä moraines and the second one perpendicular to them. The bedrock valleys were visualized using sequential indicator simulation [5]. Based on 50 simulations, the probability of the surface of the bedrock being smaller than 76 metres was calculated. The bedrock valleys, possible fracture zones, are aligned with the two continuity directions (Fig. 2a). Thus, the probable direction of the DNAPL migration or pool formation are to the north-east or south-west from the Oitti spill site (s1) along the Salpausselkä moraine and to south-east along the bedrock valley from the waste disposal dump (s2). According these results, it is possible that the DNAPLs reach the water in the Päijänne tunnel in south-western part of the study area along the bedrock valley elongated along the Salpausselkä moraine.

The flow directions of the polluted groundwater were modelled by the sequential indicator simulation applied to the water-well analyses. Water analyses for total organic halogens (AOX) were started right after the spill site was discovered. The data for the analysis come from groundwater wells and springs in the area, which are located as shown in Figure 2d. The geostatistical analysis was based on water analyses of the contaminants in 70 well-water samples. 
$2 \mathrm{a}$

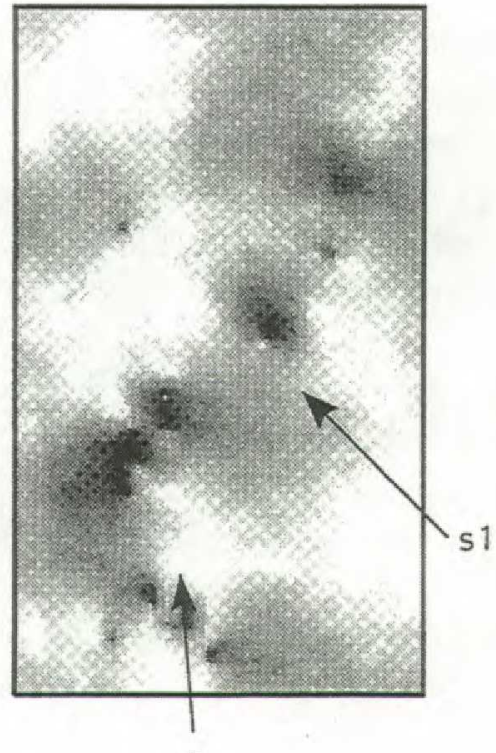

s2

$2 c$

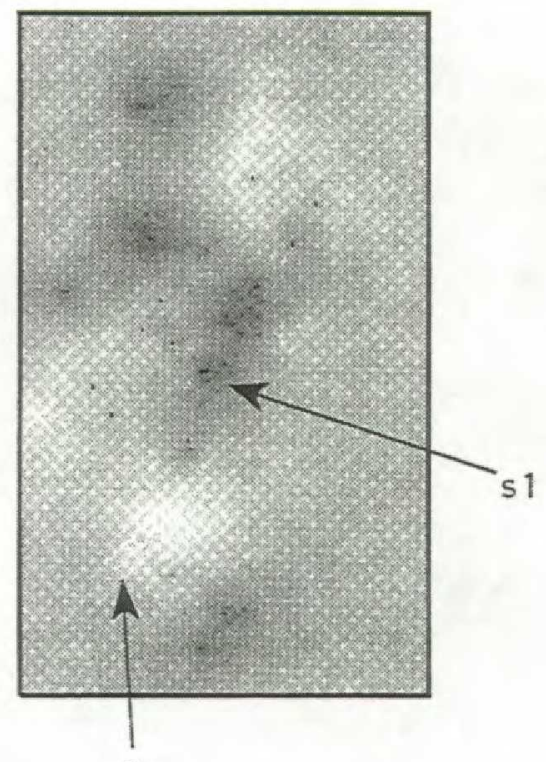

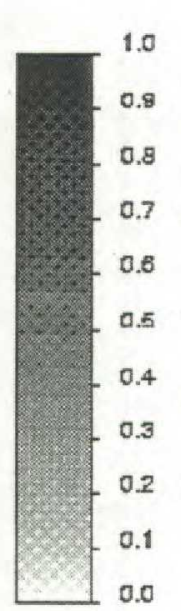

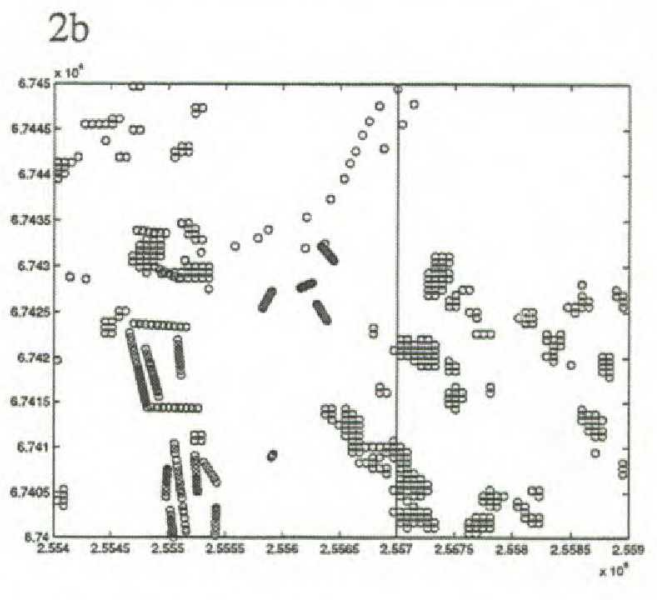

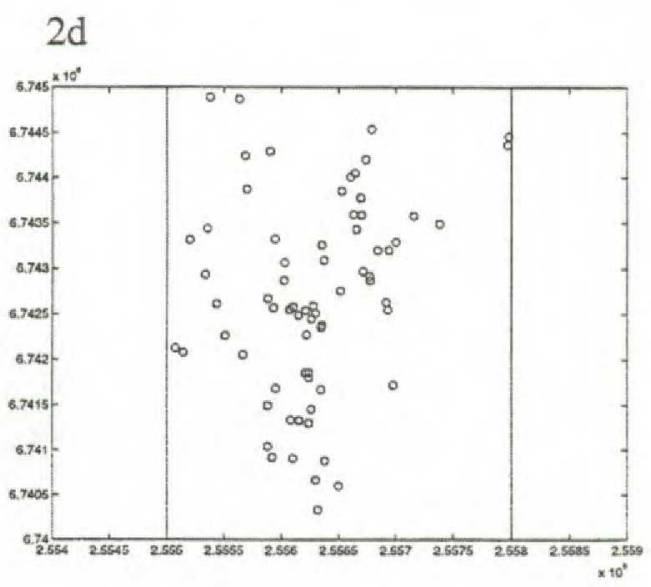

Figure 2. a) The probability of the bedrock surface being below 76 metres. b) The locations of topographic data for the bedrock surface in the area B in the western part of the study area (Fig. 1). c) The probability of the AOX content exceeding $10 \mu \mathrm{g}$ per litre. d) The groundwater sample locations in the middle part $\mathrm{C}$ of the study area. 
Figure $2 \mathrm{c}$ shows the probability of AOX values exceeding a threshold value of $10 \mu \mathrm{g}$ per liter based on 100 simulations. Figure $3 \mathrm{c}$ indicates a maximum spread from the spill site (s1) first towards the north-east and then to the south-west away from the Salpausselkä moraine (Fig. 2c) along the bedrock valleys, however not the deepest ones (Fig. 2a). In the latter direction, the polluted groundwater may reach the Päijänne tunnel. The polluted groundwater from waste dumping site ( $\mathrm{s} 2$ ) flows to south-east.

\section{Conclusions}

The comlex structure of the Salpausselkä moraines together with the fractured bedrock topography make the modelling of the contaminant migration difficult. The present study gives, however, some indications for the directions of the contaminant migration and some clues for the future study.

Ground penetrating radar is effective in a study of the detail structure of the surficiall deposits. In this case, it should be used more widely to map the clay layers, especially to find the places were the DNAPL could be pooled and may form a new source for pollution in future. Refraction seismic give the approximation of the bedrock topography. However, more seismic profiling should be done on the Salpausselkä moraines and perpendicular the direction of ridges.

Based on this study, the deepest bedrock valleys are oriented along the Salpausselkä moraine and perpendicular to it (Fig. 2a). The heavy DNAPL solvent may migrate to these valleys and form pools. In the worst case, DNAPLs may migrate to the Paijänne tunnel along the bedrock valley in the direction of the Salpausselkä moraine in the south-western part of the study area (Fig. 1 and Fig. 2a). Figure $2 c$ indicates a maximum spread from the spill site (s1) first towards the north-east and then to the south-west away from the Salpausselkä moraine (Fig. 2c) along the bedrock valleys, however not the deepest ones (Fig. 2a). In the latter direction, the polluted groundwater may reach the Päijänne tunnel. The polluted groundwater from waste dumping site (s2) seems to flow to south-east (Fig. 2d).

\section{References}

1. Jouko Varis, secretary of the environmental affairs in Oitti - a personal communication.

2. Geological Survey of Finland -The map of surficial deposits. Map sheet $213304,1987$.

3. Peltoniemi, Markku, Laine, Eevaliisa, Hänninen, Pauli, Mellett, James S. and Silvennoinen, Hannu - Geophysical surveys at the Oitti DNAPL spill site, southern Finland. Proceedings of the Symposium on the Application of Geophysics to Engineering and Environmental Problems, April 28 - May 2., 1996, pp 971 - 979.

4. Niini, Heikki - A study of rock fracturing in valleys of Precambrian bedrock. Fennia 97, N:o 6 (1968).

5. Deutsch, Clayton V. and Journel, André G. - GSLIB, Geostaistical Software Library and User's Guide. New York, Oxford. Oxford University Press. 